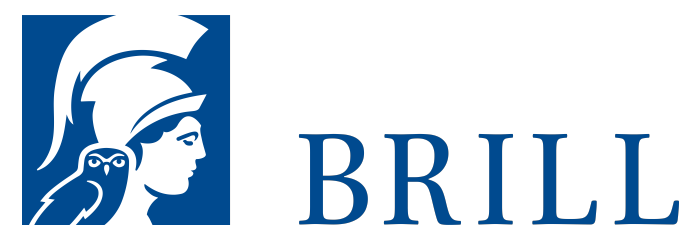

\title{
Die Görres-Gesellschaft zur Pflege der Wissenschaft
}

\author{
Streiflichter zu ihrer Geschichte?
}

Author: Rudolf Morsey

Die Görres-Gesellschaft zur Pflege der Wissenschaft zählt zu den ältesten deutschen Wissenschaftsgesellschaften in privater Trägerschaft und repräsentiert ein bedeutendes Stück deutscher Wissenschafts- und Katholizismusgeschichte. Entstanden 1876 als konfessionelle Not- und Verteidigungsgemeinschaft, förderte die Görres-Gesellschaft früh fachübergreifende Forschungsunternehmen wie etwa das »Staatslexikon«. 1941 verboten und 1948 wiederbegründet, ist bis heute ist nur ihre Leidenszeit, 1933 bis 1941, eingehend untersucht. So bilden die in diesem Band zusammengefassten acht Beiträge, auf solider Quellengrundlage Bausteine zu einer noch ausstehenden Gesamtgeschichte.

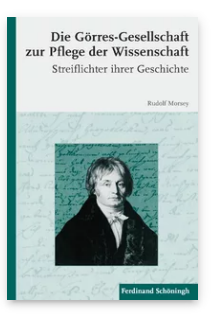

Pages: 317

Seiten

Language:

German

Subjects:

General, History

Publisher: Brill |

Schöningh

E-Book (PDF)

Released online:

og Dec 2019

ISBN: 978-3-

657-76795-3

List price

USD $\$ 54.00$

Paperback

Publication date:

22 Jul 2009

ISBN: 978-3-

506-76795-O

List price

USD $\$ 54.00$ 
For more information see brill.com

Order information: Order online at brill.com +44330 333 0049 | customerservices@brill.com Submission information: brill.com/authors

Titles published by Brill | Fink, Brill | mentis or Brill | Schöningh: +49(o)715413279216| brill@brocom.de 